\section{超精密位置決め専門委員会の活動の 現状と今後}

\author{
超精密位置決め専門委員会 \\ 吉本茂香 (東京理科大学) \\ 大橋康二 (ケーエスエス (株)
}

超精密位置決め専門委員会は, 1989 年に設置してから， 約 30 年経過した. 精密工学会の中では, 古参専門委員会 の一つである.

委員数は, 法人委員 81 社, 個人委員 (原則として, 大 学などの教官, 公立研究所勤務者など） 55 名である (2008 年 9 月現在).

定例的な集まりは，年間 $4 ， 6 ， 9 ， 11$ 月，次年度 1 月に 開催される．３小委員会（アクチュエータ，センサ，モー 夕）による毎回 2 件の事例発表会と設定された主テーマに 基づく 3 件程度の関連技術の講演会, この数年間, 毎回 100 名前後の参加となっている。この集まりの終了後, 無 料の懇親会を開催しているが，こちらにも50名前後の参 加があり，自由な話し合いなどから，共同研究などの発足 に結びついた事例も少なくない.

今後も下記のような活動を含め, より充実した内容で継 続していきたい.

(小委員会活動)

4 年ごとに実施のアンケート実施

文献調査小委員会による関連文献の探索（JST 抄録集 「機械工学編」などによる). 文献題名集発行.

（国際会議 略称“ICPT”開催）

隔年に日本，韓国で交互に開催.

2002 年の日韓合同会議，2004 年には発展的に国際会議 となり，浜松市で開催。併催小展示会も実施. 2006 年は 韓国済州島で開催. 本年 2008 年は浜松市で開催. 毎回, Proceedings（日本開催時, CD-ROM 添付）発行.

(展示会への協力)

2007 年より，オプトロニクス社が主催する「ポジショ ニング Expo」の併催セミナー企画で協力. 講師は, 大部 分を本専門委員会委員が担当. 2008 年を含め, 今後も継 続的に協力して講師派遣予定.

(出版協力)

2000 年に「次世代精密位置決め技術」（フジ・テクノシ ステム刊).

2009 年，その後の技術成果を主体にまとめた便覧的な ものを発行予定（編集完了）.

(既刊前刷集登載 DVD 作成)

既刊前刷集，アンケート報告書全文などを登載する DVDを 2008 年度中に作成，委員に配布予定.

\section{知能メカトロニクス専門委員会 活動報告}

\author{
知能メカトロニクス専門委員会幹事・事務局 \\ 秦 清治（香川大学）
}

知能メカトロニクス専門委員会は, 1994 年から 2 年間 設置された知能化メカトロニクス調査研究分科会を継続す る形で, 1996 年 7 月発足した。本委員会の設立の趣旨は, 技術的にはロボットを中心としたメカトロニクス技術に関 する調査研究を主眼とするものであるが，特に香川県とい う地域を拠点とし, 地域の課題を中心にすえた活動を行う 分科会として, 必ずしも学会での活動が活発でなかった地 域技術者の活性化, 学会への参画を狙ったものである. 地 域の課題としては, 高齢化・過疎化を問題意識として取り 上げ，工場自動化などに加えて，高齢者世帯や老齢者の支 援施設での介護支援技術，農業自動化などにも焦点を当て るものである. メンバーには, 地域を活動拠点とする企業 や，地域の公設試なども多数含まれている.

活動の基本的な形態は, 年 4 回の研究会活動であるが, そのうち 1 回は, 地域の大学等の研究室紹介を主眼とした 研究発表の場として, 交流会としての性格をもたせてい る. また, 毎年 1 回の総会の特別講演は, メカトロニクス フォーラムとして地域に公開し, 会員以外の方々にも精密 工学会や知能メカトロニクス専門委員会の活動に触れてい ただいている。この案内は, 学会関係者だけでなく, 地域 の財団や経済同友会, 大学の共同研究センターなどの連絡 網を通じて, 地域の関係者に紹介されている. メカトロニ クスフォーラムは, 本研究会活動だけでなく, 本委員会が 共同企画者として参画する学会や国際会議にも併設をお願 いすることが多く，現在までに30 回開催されている，

また，本委員会の特色としては，地域からの発信の担い 手としての活動も展開していることであり，その中でも， 本会が企画母体として 1996 年から始めた知能メカトロニ クスワークショップは, 20 年度には 13 回目を迎えて継続 されている。本ワークショップは, 瀬戸内海を囲む 6 地域 の大学等で持ち回る形で開催されており, 地域研究者・開 発者の交流の場としての役割には大きいものがある.

また，精密工学会が主催するViEW， DIA などのワー クショップなどにも共同企画委員会として加わっており, 地域の空口としての役割も果たしてきている.

以上のように, 地域の活動をべースに, 地域交流, 地域 から近隣, 全国, そして世界への活動展開の場として, 本 委員会は機能してきており, 今後ともこの活動を展開, 発 展させていきたいと考えている. 